\title{
Effects of global climate change on the US forest sector: response functions derived from a dynamic resource and market simulator
}

\author{
Bruce A. McCarl ${ }^{1, *}$, Darius M. Adams ${ }^{2}$, Ralph J. Alig ${ }^{3}$, Diana Burton ${ }^{4}$, \\ Chi-Chung Chen ${ }^{1}$ \\ ${ }^{1}$ Department of Agricultural Economics and ${ }^{4}$ Department of Forest Science, Texas A\&M University College Station, \\ Texas 77843, USA \\ ${ }^{2}$ Department of Forest Resources, Oregon State University, Corvallis, Oregon 97331-5703, USA \\ ${ }^{3}$ US Department of Agriculture, Forest Service, Pacific Northwest Experiment Station, 3200 SW Jefferson Way, Corvallis, \\ Oregon 97331, USA
}

\begin{abstract}
A multiperiod, regional, mathematical programming economic model is used to evaluate the potential economic impacts of global climatic change on the US forest sector. A wide range of scenarios for the biological response of forests to climate change are developed, ranging from small to large changes in forest growth rates. These scenarios are simulated in the economic forest sector model and results are summarized in response functions that may be used instead of rerunning the model as improved or altered biological response scenarios arise. The response functions are used to characterize broad impacts of climate change on the sector. We find that aggregate impacts (across all consumers and producers in the sector) are relatively small but that producers income and future welfare 30 to $40 \mathrm{yr}$ in the future are most at risk. The forest sector is found to have adjustment mechanisms that mitigate climate change impacts, including interregional migration of production, substitution in consumption, and altered stand management.
\end{abstract}

KEY WORDS: Climate change $\cdot$ US forest $\cdot$ Sector analysis $\cdot$ Response function Resale or republication not permitted without written consent of the publisher

\section{INTRODUCTION}

Global climate change may modify the growth and geographic distribution of US forests. Although several studies have attempted to estimate the biological effects of climate change on forests, the magnitude and direction of these effects remain uncertain (see Joyce et al. 1995, Sohngen \& Mendelsohn 1998, Winnett 1998). For example, using 6 biogeographic simulator configurations under a single weather scenario, Sohngen \& Mendelsohn (1998) found that total inventory volume of Southern pine ranges between $28 \%$ above and $29 \%$ below base levels. For western Douglas-fir, their estimates range from $35 \%$ above to $35 \%$ below base levels. Such wide ranges are not very informative.

*Senior author; E-mail: mccarl@tamu.edu.

The other authors each made equal contributions
Research to clarify forest growth impacts continues, but it is clear that a comprehensive understanding will emerge only gradually. This uncertainty in growth impacts leads to similar ambiguity in derivative studies of the effects of global change on the industries and consumers that use the forest resource.

The present study investigates the potential economic impacts within the forest sector due to alterations in forest growth arising from global climate change. We employ a dynamic model of the US forest sector (FASOM, described in Adams et al. 1996, 1997 and Alig et al. 1998) that simulates both timber market and resource management responses. Given the considerable uncertainty about the biological impact of global change on forests, however, we do not examine a single scenario or group of scenarios but rather develop a set of response functions. Estimated with FASOM simulation results generated across a broad 
range of possible biological outcomes, the response functions summarize the model projections of an array of measures of sector performance as stimulated by a wide variety of changes in forest growth. Employing these functions, analysts can explore particular climate change scenarios and rapidly generate projections of the associated economic effects as new findings arise on biological growth impacts. The following sections of this paper describe problem background, prior studies and then the methods employed to develop the response functions. Subsequently, we illustrate how the resulting functions can be used to provide specific and general characterizations of impacts.

\section{FOREST RESOURCE AND PRODUCT MARKET IMPACTS OF CLIMATE CHANGE}

Global atmospheric change would affect tree growing conditions, but the nature of the altered climate could vary substantially in different regions. Impacts on forests arise from increases in atmospheric $\mathrm{CO}_{2}$ concentration, change in temperature regimes, and variations in patterns of rainfall over the year. These shifts would alter basic physiological processes in trees and soils, influencing tree growth and the yield of commercial products over time. The actual time pattern of change will be complex, owing to lags between atmospheric changes, climate effects and biological responses (see Winnett 1998 for a review of the growth change issues). Economic impacts resulting from growth changes will be further delayed due to the length of forestry rotations, generally involving 2 or more decades. ${ }^{1}$ Thus, an examination of the effects of climate change on forests needs to consider forest rotation decisions as well as lags between the onset of climate change and realized biological impacts. These dynamic aspects of climateinduced changes in forest yield need to be addressed with a model that recognizes the temporal characteristics of both product markets and the forest resources.

Climate change may alter the quantities of forest products harvested in a substantial fashion. In regions where climatic effects reduce growth, smaller volumes will be available for harvest in both existing forest stands and in those replanted after harvest in the future. The reverse would be true in regions experiencing increased growth. Such changes will alter the supply of products to national and international markets, changing the prices of forest products and the economic welfare of both consumers and producers of these products. Consumers, in turn, will shift their patterns of consumption between forest and non-forest products. Producers will change both the

${ }^{1}$ Forest rotation or harvest age is the length of time that trees are grown from planting to final harvest types of management they practice (planting, thinning, and other cultural treatments) and the ages at which they harvest trees in various ways, depending on the nature of the owner (private or public). Further, since climate change is global in nature and a considerable portion of US softwood timber consumption is of Canadian origin, the implications of climate change for harvest in Canada must also be recognized.

The difference between climate change effects on existing trees and trees planted at some future date bears further emphasis. Existing trees will be affected only in their incremental growth from the current period to harvest age as climate change occurs. Trees planted in the future will grow entirely in an environment with altered climate. Thus, growth rate responses must differ for existing and future trees. For existing trees, current volume will remain unchanged but future incremental growth may vary. For new trees, the entire future time path of volume growth and product yield may be altered.

\section{PAST STUDIES OF THE FORESTRY EFFECTS OF CLIMATE CHANGE}

Much has been written about the potential effects of climate change. Several studies have explored climate change implications for the agricultural sector (e.g., Adams et al. 1990, 1999, Kane et al. 1992, and others as reviewed in Adams et al. 1998 and Lewandrowski \& Schimmelpfennig 1999). In forestry, however, knowledge of the biological response is limited. Comprehensive experiments have not been completed on how trees behave over long periods when exposed to alternative climates, nor can observations on existing forests be used with confidence since $\mathrm{CO}_{2}$, moisture and temperature regimes of the type that may be associated with future climate change are not observable. Little is known as well about how experimental results on responses of individual trees generalize to stand and forest levels (Winnett 1998).

A few studies have examined potential impacts of climate change on the forest sector. Van Kooten \& Arthur (1989) studied hypothetical increases in the biomass of certain Canadian forests. They conclude that the overall implications of climate change for economic welfare may be negative for Canada. ${ }^{2}$ In a later study van Kooten (1990) examined the impact of 5 and $7.5 \%$ increases in Canadian harvests together with positive and negative changes of similar magnitudes for US

\footnotetext{
${ }^{2}$ Economic welfare refers to the combination of producer profits and consumer well-being measured in monetary terms which results from the interaction of supply and demand in a market. Forces that shift demand and supply influence the overall level of welfare in the market and the distribution of welfare between producers and consumers
} 
harvests. He concluded that consumers in both countries would benefit, but that producers would lose, and that the overall Canadian impact would be positive only if US harvests declined.

Perez-Garcia et al. (1997) examined climate change effects on the world forest economy using a single-year model. They assumed climate change would stimulate increased net primary production and found that as a consequence timber became more abundant, price fell, and consumption increased. Also major timber producers such as Canada were found to receive a positive, but small, economic gain, while the United States benefited under all scenarios examined. In their study, adaptation (e.g., altering management or replanting with different species of trees to change forest types in a region) was ignored, with forest management actions treated as external to the analysis.

Callaway et al. (1994) employed an early version of FASOM together with climate and ecological models to examine a doubled $\mathrm{CO}_{2}$ equilibrium climate. Their study estimated how harvests could shift over time, along with changes in tree planting investment, as part of the dynamic adjustment of markets and capital stocks to global change. The study used timber demand information from the USDA Forest Service's Resources Planning Act (RPA) Assessment database and modeling systems (see, e.g., Haynes et al. 1995, Adams \& Haynes 1996) and resource information similar to that used in the Joyce et al. (1995) study. The treatment by Callaway et al. (1994) of existing forests was somewhat unrealistic, however, in that initial tree inventories as well as subsequent growth were adjusted instantaneously for climate change impacts. Further, they did not adjust production either from Canadian forests or forests on public lands in the United States.

Sohngen \& Mendelsohn (1998) linked a dynamic model of US timber markets with a large-scale biogeographic model. This application provided more information on the dynamic adjustment of markets and resources than the Perez-Garcia et al. (1997) study, although it also assumed a doubling of $\mathrm{CO}_{2}$ to an equilibrium level that leads to steady-state biogeographical results. The market model employed in this study is less complex than the FASOM model used by Callaway et al. (1994), containing less regional and ownership detail. Similar to Perez-Garcia et al. (1997), Sohngen \& Mendelsohn (1998) found that climate change expanded long run timber supply under all scenarios. Welfare effects were relatively small, with an average present value of about $+\$ 20$ billion. ${ }^{3}$ The analysis sug-

\footnotetext{
${ }^{3}$ This is the adjustment due to the climate change scenario. With the total market welfare level (the sum of producer and consumer benefits) at roughly $\$ 283$ billion, this change represents about a $+7 \%$ shift
}

gests that human actions in markets can mitigate, and even reverse, resource production shifts induced by climate change (Sohngen et al. 1998).

Rather than drawing directly on growth change estimates derived from ecological models, Burton et al. $(1994,1998)$ considered hypothetical cases of extreme biological response, representing probable bounds on the range of forest response to stresses induced by global change. The study used the FASOM model to look at 3 scenarios of extreme change in growth induced by global climate change: a $50 \%$ increase in decadal growth rates on timberland in both the US North and South; a $50 \%$ decrease in both regions; and a $50 \%$ increase in the North and a $50 \%$ decrease in the South. Simulation results indicated that producers' impacts exceed those on consumers and that Southern producers are affected more than producers in other regions.

\section{BASE MODEL EMPLOYED FOR SIMULATING FOREST CLIMATE CHANGE EFFECTS}

The forestry portion of the FASOM model, which is an acronym for Forest and Agricultural Sector Optimization Model, as documented in Adams et al. (1996, 1997) and Alig et al. (1998), was employed to derive projections of forest sector production, prices and welfare given a climate change scenario. FASOM is a multiperiod, non-linear, price-endogenous, mathematical-programming, economic model that provides $100 \mathrm{yr}$ projections. FASOM depicts the volume removed, area harvested, and management investment decisions for industrial and non-industrial private forests, together with the consumption of timber products and market prices in the US forest sector by major forest region. Products comprise fuelwood, sawtimber, and pulpwood for both softwood and hardwood species. Acres harvested from public lands and the import supply of timber from Canada are assumed to be determined by forces outside the present analysis and are taken as exogenous input although volumes are affected by climate change.

The biological effects of climate change are introduced in the analysis by modifying timber yields in FASOM. The FASOM yields (volumes per unit area) vary by the age of the forest and an array of conditions that reflect the quality of the growing site. The example in Table 1 gives the total volume per unit area in a forest stand at the end of year 1 as $Y_{1}$, in year 2 as $Y_{2}$, and in year $t$ as $Y_{t}$. Suppose we anticipate a decrease in the growth rate of $\delta$ (for $0 \leq \delta \leq 1$ ) induced by climate change. Total volume in period 1 would be adjusted downward by $\delta$. In all subsequent periods the volume at the end of the period would be the volume at the 
Table 1. Yields (volume per unit area) by age for a forest with and without climate change, illustrating the application of an assumed yield reduction of $\delta$

\begin{tabular}{|lcc|}
\hline $\begin{array}{l}\text { Age in } \\
\text { periods }\end{array}$ & $\begin{array}{c}\text { Original } \\
\text { yield }(Y)\end{array}$ & $\begin{array}{c}\text { Yield altered by } \\
\text { climate change }(Z)\end{array}$ \\
\hline 0 & 0 & 0 \\
1 & $Y_{1}$ & $Z_{1}=Y_{1}(1-\delta)$ \\
2 & $Y_{2}$ & $Z_{2}=Z_{1} \times\left[1+\left(Y_{2}-Y_{1}\right) / Y_{1} \times(1-\delta)\right]$ \\
$t \geq 3$ & $Y_{t}$ & $Z_{t}=Z_{t-1} \times\left[1+\left(Y_{t}-Y_{t-1}\right) / Y_{t-1} \times(1-\delta)\right]$ \\
\hline
\end{tabular}

beginning of the period times 1 plus the altered growth rate. The altered growth rate is the original growth rate in the yield table, $\left(Y_{t}-Y_{t-1}\right) / Y_{t-1}$, times 1 minus $\delta$. A similar approach was used to treat existing stands. However, for a stand of trees that is $t-1 \mathrm{yr}$ old at the beginning of the analysis, only the formula for a stand at age $t$ is employed, treating $Y_{t-1}$ as a constant and leaving the initial volume unchanged.

Modifications were also made in public cut and Canadian import supply to reflect the impacts of climate change. Volumes from these sources were adjusted by the average percent change in harvest observed in comparable regions on private lands in the United States.

\section{RESPONSE FUNCTION METHODS}

Lacking definitive estimates of the impacts of global change on forest growth, a great many runs of the FASOM model under alternative growth scenarios may be required to assess the potential variability of the outcomes of interest in any given analysis. This poses a substantial analytical burden. As an alternative, we propose the use of response functions derived from the model's results. These functions summarize and forecast model results for a wide range of economic measures as functions of climate-induced changes in forest yields (the $\delta$ 's noted above). For each economic measure, a set of model projections or responses (the vector $\boldsymbol{R}$ ) is generated over a large number of possible changes in forest yield (the vector $\boldsymbol{\delta}$ ), with all other conditions in, and inputs to, the model being held constant. The projected response values are then regressed on the yield changes using a suitably flexible functional form to estimate the relation $\boldsymbol{R}=\mathrm{f}(\boldsymbol{\delta})$, which is the response function of the model for that measure.

In the present analysis, model response is computed as the difference between the outcome under a change in growth and the outcome in the base (no change) case. To reduce the scope of the problem, we differentiate between growth changes in only 2 broad regions within the United States, North and South, for softwood and hardwood species. ${ }^{4}$ Because timber production is limited in the regions outside the southern and northern regions as here defined, we assume that the growth change in these other areas is the average of the changes in the North and South. Thus, the response functions will give the change in model projections as a function of growth changes in 4 region/ species groups: southern softwoods (SS), southern hardwoods (SH), northern softwoods (NS), and northern hardwoods $(\mathrm{NH})$. We employ a quadratic functional form with both squared and interaction terms and without an intercept as:

$$
R_{t}=\sum_{r} \alpha_{r} \delta_{r}+\frac{1}{2} \sum_{r} \sum_{s} \beta_{r s} \delta_{r} \delta_{s}
$$

where $R_{t}$ is the model response for a particular economic measure (change from base), $\delta_{r}$ and $\delta_{s}$ are the changes in growth for the 4 region-species combinations, $\alpha$ 's and $\beta$ 's are the coefficients to be estimated in the regression, and $r$ and $s$ are the sets of region and species combinations ranging over the values $\mathrm{SS}, \mathrm{SH}$, NS, and NH.

Because we measure responses as changes from the base levels, functions (Eq. 1) have a value of 0 when all the $\delta$ 's are zero and there is no change from the no climate change, base condition.

We estimated response functions for 149 different measures of market and welfare impacts, which are listed in Table 2. The dynamic and geographic nature of the dependent variables varied. Some were defined on a decade-by-decade basis from the first to the fifth decade following onset of the growth changes. Some were defined regionally, with results given for the South and the North. Others comprise only a single present net value computed on a national basis.

The data from which Eq. (1) was estimated were derived from 481 growth scenarios run with the FASOM model, designed to span both limited cases and the extremes of potential climate change impacts: (1) 361 systematic combinations of changes in decadal growth rates $(0, \pm 5, \pm 10$, and $\pm 15 \%)$ for hardwoods and softwoods in the northern and southern regions ${ }^{5}$, plus (2) 120 random alterations, where the random numbers were drawn from a uniform distribution between plus and minus $15 \%$ for growth rates by region and species. The form of the response surface for any given measure is unknown. The systematic grid of 361 points provides a basic sample of the surface. The 120 random points provide information on behavior of the

\footnotetext{
${ }^{4}$ The North region includes the Pacific Northwest, Rocky Mountains, Lake States and Northeast. The South comprises the South East and South Central regions. The specific regional definitions are in Adams et al. $(1996,1997)$
} 
Table 2. Economic impact measures for which response equations were estimated. Entries in cells indicate the number of separate measures. Total equations estimated for each measure is given by decades $\times$ national + decades $\times$ regional. National: an equation for the national value of these variables was estimated; regional: one equation for each region, North and South, was estimated for these variables. Foreign surplus refers to the net welfare gain derived from log import suppliers' surplus and log export consumers' surplus. NPV: net present value

\begin{tabular}{|c|c|c|c|}
\hline Dependent variable & National & Regional & Unit \\
\hline NPV producers' surplus & 1 & & Million $2000 \$$ \\
\hline NPV consumers' surplus & 1 & & Million $2000 \$$ \\
\hline NPV foreign surplus & 1 & & Million $2000 \$$ \\
\hline NPV total welfare & 1 & & Million $2000 \$$ \\
\hline Producers' surplus ${ }^{\mathrm{a}}$ & 5 & 10 & Annual annuity in million real $2000 \$$ by decade \\
\hline Consumers' surplus $^{a}$ & 5 & & Annual annuity in million real $2000 \$$ by decade \\
\hline Total social welfare ${ }^{a}$ & 5 & & Annual annuity in million real $2000 \$$ by decade \\
\hline Softwood sawtimber price ${ }^{a}$ & 5 & & Price per cubic foot in real $2000 \$$ in decade \\
\hline Hardwood sawtimber price ${ }^{a}$ & 5 & & Price per cubic foot in real $2000 \$$ in decade \\
\hline Softwood pulp price ${ }^{a}$ & 5 & & Price per cubic foot in real $2000 \$$ in decade \\
\hline Hardwood pulp price ${ }^{a}$ & 5 & & Price per cubic foot in real $2000 \$$ in decade \\
\hline Softwood sawtimber production ${ }^{\mathrm{a}}$ & 5 & 10 & Thousand cubic feet harvested in decade \\
\hline Hardwood sawtimber production ${ }^{\mathrm{a}}$ & 5 & 10 & Thousand cubic feet harvested in decade \\
\hline Softwood pulp production ${ }^{\mathrm{a}}$ & 5 & 10 & Thousand cubic feet harvested in decade \\
\hline Hardwood pulp production $^{a}$ & 5 & 10 & Thousand cubic feet harvested in decade \\
\hline Harvested softwoods ${ }^{a}$ & 5 & & Thousand acres harvested in decade \\
\hline Harvested hardwoods ${ }^{a}$ & 5 & & Thousand acres harvested in decade \\
\hline Total harvested acres ${ }^{a}$ & & 10 & Thousand acres harvested in decade \\
\hline Management intensity $^{a}$ & & 10 & Index from 1 to 4 with 4 highest in decade \\
\hline Rotation age $^{\mathrm{a}}$ & & 10 & Age in years by species in decade \\
\hline
\end{tabular}

surface within the grid and sufficient variation in the explanatory variables themselves (the $\delta_{r}{ }^{\prime} \mathrm{s}$ in Eq. 1) to prevent singularity in the matrix of regressors.

\section{SCENARIO PROJECTIONS AND RESPONSE FUNCTION RESULTS}

Coefficients of the set of 149 regressions were estimated using standard methods of ordinary least squares. Within the set of estimates, one-third exhibited an $\mathrm{R}^{2}$ statistic of at least $0.9,55 \%$ were above 0.7 ,

${ }^{5}$ To create these 361 systematic combinations we constructed 19 cases of yield change for hardwoods and softwoods and then ran all interactions of those for the South and North regions $(19 \times 19=361)$. The 19 cases consisted of the 7 softwood cases with changes of $-15,-10,-5,0,+5,+10$, and $+15 \%$ plus associated hardwood cases. Because tree species in a given region will be subject to the same general changes in growing conditions, it is unlikely that we will observe cases where the hardwood and softwood growth responses are dramatically different. Specifically, we assume that hardwood and softwood growth changes would differ by no more than $\pm 5 \%$. When softwood effects were $-15 \%$ we considered hardwood effects of -15 and $-10 \%$. When softwoods were affected by $-10 \%$ we considered $-15,-10$ and $-5 \%$ cases for hardwoods. This yields 3 hardwood cases for each of the 5 central softwood cases $(-10$ through $+10 \%)$ and 2 for the 2 extremes $(-15$ and $+15 \%)$ or a total of 19 cases
$75 \%$ were above 0.5 , and $90 \%$ were above 0.4 . A full listing of all the response function parameters estimated is available as a GAMS file or as a comma delimited file for spreadsheet import on the Web page http://agrinet.tamu.edu/mccarl.

To illustrate the results, consider the regression response functions for the change in the net present value of economic welfare accruing to producers, consumers, foreign interests, and the total market in millions of year 2000 dollars as given in Table $3 .{ }^{6}$ The producers here are the private owners of forests in all regions of the United States who harvest timber for commercial products. Their economic welfare is measured by their profits in the sale of timber beyond their costs of growing the trees and of foregone interest involved in waiting until they are mature. Consumers comprise all users of harvested timber (for housing, manufacturing, shipping, paper and board, etc.). Their welfare or benefit from the market transaction is measured as the difference between their expenditures if forced to pay the highest price they would be willing to pay to still consume timber and their actual payments at the equilibrium market price. This difference represents a 'savings' or 'surplus' to consumers. Foreign interests are

\footnotetext{
${ }^{6}$ The table also contains a base case value for the parameter being estimated, $t$ statistics, and the overall equation $\mathrm{R}^{2}$ (adjusted for absence of an intercept)
} 
Table 3. Response function parameters for a positive $1 \%$ change in yield giving estimated effects on net present value of forest sector welfare by market participant in million $2000 \$$. Numbers in parentheses are the ratios of the coefficients to their estimated standard errors. SS is the percentage change in southern softwood yield over a decade, $\mathrm{SH}$ the change in southern hardwood yield, NH the change in northern hardwood yield over a decade and NS the change in northern softwood yield. SHNH, SSNS, etc. are cross-product (interaction) terms and $\mathrm{NH} 2$, etc. are squared terms

\begin{tabular}{|c|c|c|c|c|}
\hline \multirow{2}{*}{ Regressor } & \multicolumn{4}{|c|}{ Market participant } \\
\hline & Producers & Consumers & Foreign & Total \\
\hline Base value: & 251315 & 2860082 & 7107 & 3212872 \\
\hline $\mathrm{SH}$ & $\begin{array}{r}-2692.86 \\
(48.79)\end{array}$ & $\begin{array}{r}2935.43 \\
(47.74)\end{array}$ & $\begin{array}{c}4.11 \\
(16.24)\end{array}$ & $\begin{array}{c}363.42 \\
(47.67)\end{array}$ \\
\hline SS & $\begin{array}{r}-5079.34 \\
(91.82)\end{array}$ & $\begin{array}{c}6704.61 \\
(108.80)\end{array}$ & $\begin{array}{c}27.39 \\
(107.90)\end{array}$ & $\begin{array}{c}1596.53 \\
(208.92)\end{array}$ \\
\hline $\mathrm{NH}$ & $\begin{array}{r}-2441.34 \\
(42.47)\end{array}$ & $\begin{array}{r}2796.49 \\
(43.67)\end{array}$ & $\begin{array}{c}5.82 \\
(22.04)\end{array}$ & $\begin{array}{c}395.97 \\
(49.86)\end{array}$ \\
\hline NS & $\begin{array}{r}-2601.70 \\
(44.95)\end{array}$ & $\begin{array}{r}3414.36 \\
(52.96)\end{array}$ & $\begin{array}{c}15.08 \\
(56.78)\end{array}$ & $\begin{array}{c}1844.07 \\
(230.66)\end{array}$ \\
\hline SH2 & $\begin{array}{r}-17.75 \\
(3.05)\end{array}$ & $\begin{array}{l}19.68 \\
(3.03)\end{array}$ & $\begin{array}{c}0.16 \\
(6.03)\end{array}$ & $\begin{array}{c}-0.51 \\
(0.64)\end{array}$ \\
\hline $\mathrm{SS} 2$ & $\begin{array}{l}56.54 \\
(9.73)\end{array}$ & $\begin{array}{c}-81.72 \\
(12.63)\end{array}$ & $\begin{array}{c}-0.27 \\
(10.22)\end{array}$ & $\begin{array}{c}-20.07 \\
(25.01)\end{array}$ \\
\hline NH2 & $\begin{array}{r}-18.06 \\
(3.17)\end{array}$ & $\begin{array}{l}16.24 \\
(2.56)\end{array}$ & $\begin{array}{c}0.03 \\
(1.29)\end{array}$ & $\begin{array}{c}-0.62 \\
(0.79)\end{array}$ \\
\hline NS2 & $\begin{array}{c}7.17 \\
(1.16)\end{array}$ & $\begin{array}{l}-6.03 \\
(0.87)\end{array}$ & $\begin{array}{c}-0.12 \\
(4.25)\end{array}$ & $\begin{array}{c}4.70 \\
(5.49)\end{array}$ \\
\hline $\mathrm{SHNH}$ & $\begin{array}{l}56.60 \\
(7.74)\end{array}$ & $\begin{array}{r}-63.91 \\
(7.84)\end{array}$ & $\begin{array}{c}-0.03 \\
(0.95)\end{array}$ & $\begin{array}{c}-11.17 \\
(11.06)\end{array}$ \\
\hline SSNS & $\begin{array}{l}121.05 \\
(16.30)\end{array}$ & $\begin{array}{r}-145.38 \\
(17.57)\end{array}$ & $\begin{array}{c}-0.59 \\
(17.25)\end{array}$ & $\begin{array}{c}-24.59 \\
(23.97)\end{array}$ \\
\hline SHNS & $\begin{array}{r}-16.16 \\
(2.18)\end{array}$ & $\begin{array}{l}15.01 \\
(1.82)\end{array}$ & $\begin{array}{c}0.02 \\
(0.58)\end{array}$ & $\begin{array}{c}0.11 \\
(0.11)\end{array}$ \\
\hline SSNH & $\begin{array}{l}24.38 \\
(3.17)\end{array}$ & $\begin{array}{r}-30.79 \\
(3.60)\end{array}$ & $\begin{array}{c}-0.04 \\
(1.08)\end{array}$ & $\begin{array}{c}-7.14 \\
(6.72)\end{array}$ \\
\hline SHSS & $\begin{array}{r}-35.62 \\
(5.49)\end{array}$ & $\begin{array}{l}34.96 \\
(4.84)\end{array}$ & $\begin{array}{c}0.11 \\
(3.74)\end{array}$ & $\begin{array}{c}0.11 \\
(0.12)\end{array}$ \\
\hline NHNS & $\begin{array}{l}31.74 \\
(4.32)\end{array}$ & $\begin{array}{r}-33.77 \\
(4.13)\end{array}$ & $\begin{array}{c}-0.04 \\
(1.06)\end{array}$ & $\begin{array}{c}-4.16 \\
(4.10)\end{array}$ \\
\hline $\mathrm{R}^{2}$ & 0.99 & 0.99 & 0.99 & 1.00 \\
\hline
\end{tabular}

exporters/suppliers of timber to, and importers/consumers of timber from, the United States. Their welfare arising from this trade is measured in essentially the same way as for domestic producers and consumers. The total market welfare is the sum of gains and losses realized by all the market participants (plus adjustments for receipts by public timber sellers and the costs of transporting timber from sources to users).

The response functions shown in Table 3 predict the welfare effect on these various market groups when there is a $1 \%$ change in decadal level growth in 1 or more of the region/species yield groups. Consider, for example, the data in the first column for the producers' welfare equation. The base value of producers' surplus is $\$ 251$ billion with no changes in growth due to cli- matic shifts. If growth in southern softwood yields (SS in Table 3$)$ were to rise by $1 \%(\delta=1)$ from its initial unperturbed condition $(\delta=0)$ with no other changes, producers' welfare would fall by $\$ 5.023$ billion (considering the linear and squared term or $-5.079+0.056)$. In this case an increase in growth would raise harvests in future periods but drive down prices at a faster rate, thus lowering overall producers' welfare. Looking across the other equations, this same change would raise consumers' and foreign trade surpluses by $\$ 6.623$ and $\$ 0.027$ billion, respectively, and total market surplus (including other adjustments) by $\$ 1.576$ billion.

\section{GENERAL OBSERVATIONS FROM THE RESPONSE FUNCTIONS}

The response functions provide a useful tool for examining specific climate change scenarios. They are also valuable for considering the potential variability in forest sector impacts of climate change across a broad range of possible outcomes. To illustrate this application, we develop a set of simple growth change scenarios by mechanically increasing or decreasing growth in the North and South by fixed percentages. The scenario names and definitions are: (1) None: no change in yields. (2) $\mathrm{S}-\delta$ N0: negative $\delta$ percent reduction in southern yields for softwoods and hardwoods, no change in northern yields. (3) $\mathrm{S}-\delta \mathrm{N}-\delta$ : negative $\delta$ percent reduction in southern and northern yields for softwoods and hardwoods. (4) S0 $\mathrm{N}+\delta$ : positive $\delta$ percent increase in northern yields for softwoods and hardwoods, no change in southern yields. (5) $\mathrm{S}-\delta \mathrm{N}+\delta$ : negative $\delta$ percent reduction in southern yields for softwoods and hardwoods; positive $\delta$ percent increase in northern yields for softwoods and hardwoods. The $\delta$ percent changes in these simulations allow the results to be interpreted along the lines of elasticities (the percentage change in the outcome per percent change in growth). Note that there is no $\mathrm{S}+\delta$ case, because at the time of this writing none of the currently available climate change projections suggested any expansion in growth in the South (one of the few areas of agreement among projections).

As a first step in examining variability in forest sector impacts, we consider an array of multiples of these basic scenarios. For example, we begin with the $\mathrm{S}-\delta$ $\mathrm{N}-\delta$ case and expand the reductions over the range -1 to $-20 \%$ in both the North and South (negative growth impact multiples from 1 to $20 \%$ ) or start with $\mathrm{S}-\delta \mathrm{N}+\delta$ and expand the reduction for the South over the range -1 to $-20 \%$ and the increase for the North over the range +1 to $+20 \%$. These changes are then used in the response functions (such as Table 3 ) to estimate the various economic impacts (the levels of $\delta$ are 
the values of $\mathrm{SS}, \mathrm{SH}, \mathrm{NS}$, and $\mathrm{NH}$ in Table 3). Using as examples the economic welfare measures for producers, consumers, and the market total developed in Table 3, the results of these applications are shown in Fig. 1, where the percentage change in the economic variable is plotted against the level of the growth change multiple $(\delta)$.

Fig. 1a suggests that the overall market welfare impacts of climate change on the sector may be relatively limited. Even at a growth change multiplier of 20 in all the scenarios, total welfare impacts range only from +1 to $-4 \%$ of the base. This result is not surprising, considering that the existing variation in climate and yields across the United States as a whole far exceeds the likely variation caused by climate change. Research in the agricultural sector (Adams et al. 1990, 1998, 1999, Lewandrowski \& Schimmelpfennig 1999) has reached similar conclusions, suggesting that production shifts across regions and between producers and consumers may act to contain the aggregate impacts.

This does not mean that there would be no 'distributional impacts', that is, shifts in welfare among the various groups participating in the market, with some gaining and some losing. Indeed, as suggested in Fig. 1b,c, shifts between consumers and producers may be substantial. Consumers' and producers' welfare effects are uniformly opposing (compare lines for any single scenario in Fig. 1b,c). Producers' welfare sensitivity, considering the range of impacts between the highest and lowest lines in the figure at any given multiplier, is roughly 10 times (in percentage terms) that of consumers' welfare, which in turn is roughly 5 times in percentage terms that of total societal welfare. When yields are reduced, producers' welfare shows gains while consumers' welfare shows losses. When yields increase, the opposite occurs. This seems reasonable given that the demand for forest products is fairly inelastic (insensitive to price). In such circumstances (as has been found in agricultural markets), small percentage increments in output lead to larger percentage reductions in prices, which lowers producers' welfare (profits) but increases consumers' welfare (they can consume more at a lower price). Climate change may portend some major dislocations for producers causing widespread structural adjustment, (a) NPV of Total Welfare



(b) NPV of Producers' Welfare

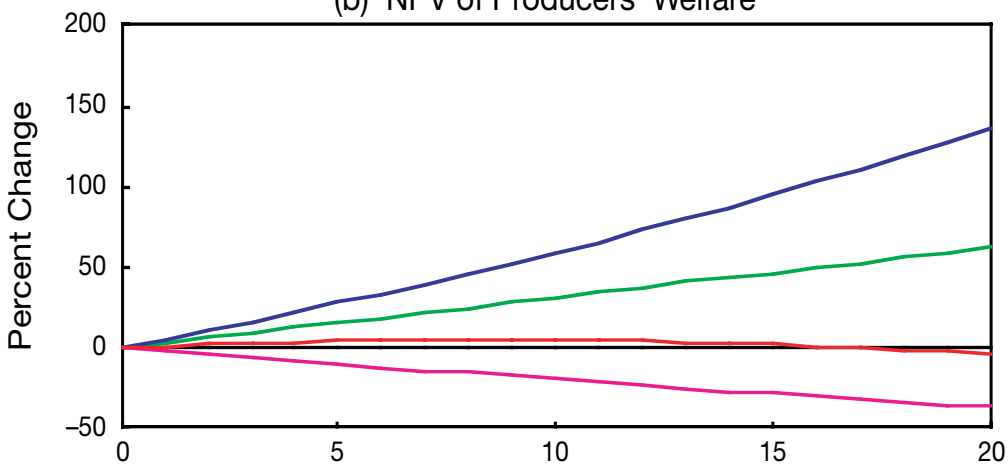

(c) NPV of Consumers' Welfare

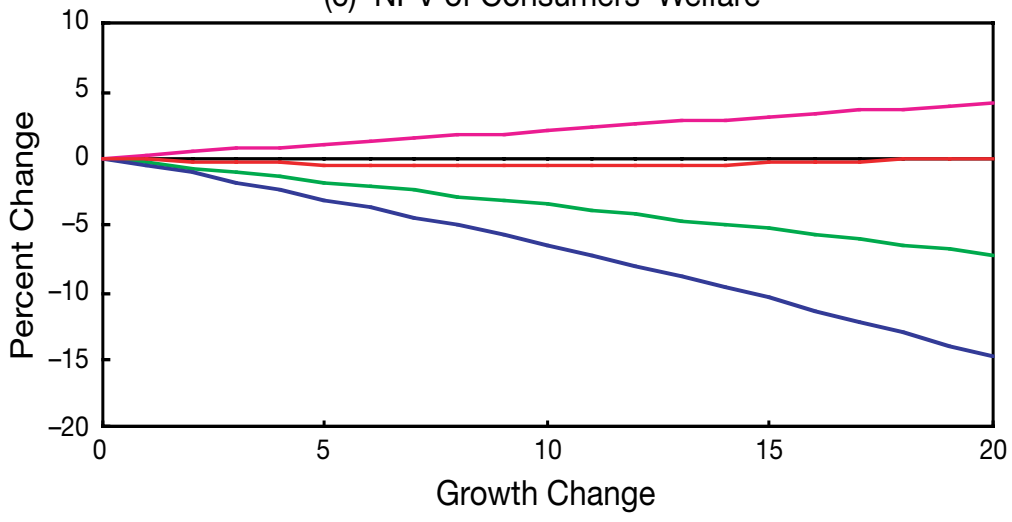

Fig. 1. Changes in the net present value (NPV) of 3 welfare measures as a function of the multiples of the simple plus and minus $1 \%$ growth change scenario. The changes in a simple scenario, such as $\mathrm{S}-1 \mathrm{~N}-1$, which involves a $1 \%$ reduction in both South and North forest growth, are expanded by 1 unit increments, producing new scenarios: $\mathrm{S}-2 \mathrm{~N}-2, \mathrm{~S}-3 \mathrm{~N}-3, \ldots, \mathrm{S}-10$ $\mathrm{N}-10, \ldots, \mathrm{S}-20 \mathrm{~N}-20$. The percentage growth changes for these scenarios are plotted on the horizontal axis $(2,3, \ldots, 10, \ldots, 20)$ and the change of the welfare measure from the BASE case on the vertical axis. Black: no climate change, blue: $\mathrm{N}-\delta / \mathrm{S}-\delta$, green: $\mathrm{S}-\delta / \mathrm{N} 0$, violet: $\mathrm{S} 0 / \mathrm{N}+\delta$, and red: $\mathrm{S}-\delta / \mathrm{N}+\delta$, where $\delta=1-20$

if climate change stimulates higher yields. On the consumers' side there is substantial welfare at risk under reductions in yields. This finding is also generally consistent with results from earlier studies to the extent that they are comparable. For example, van Kooten (1990) found that the impacts on producers from yield 
increases were likely to be negative, while consumers were likely to benefit.

Using the response functions estimated for various time periods (as indicated in Table 2), it is also possible to gain a view of economic welfare impacts over time. For the same market groups as in Table 3 and Fig. 1, we compute consumers', producers', and total market economic welfare impacts over the first 5 decades following onset of growth changes. Results plotted in Fig. 2 show the same opposing patterns of gain and loss across the basic scenarios as in Fig. 1. Both consumers' and producers' impacts expand over time as the growth changes persist (recall the compounding effects of growth change on yields), resulting in variable patterns of change in the aggregate.

At a more detailed level, adaptation of human systems has proven to be an important factor in the assessment of climate change impacts. In studies of agriculture, consideration of shifts in crop varieties, crop mixes, and other factors has been found to reduce climate change impacts by as much as $50 \%$ relative to studies that ignore adaptation (Adams et al. 1999). The FASOM model used in this study permits several forms of adaptation in the forest sector, including changes in: (1) timber management intensity, (2) hardwood/softwood species mix, (3) harvesting patterns within and between regions, (4) rotation ages, and (5) consumers' use of wood versus other products (i.e., substitution of non-wood products in consumption based on relative price).

The response functions can be readily employed to examine the adaptation issue. Fig. 3 shows estimates of regional production, total US production, prices by product, and average rotation (harvest) ages by region all for softwood products (hardwood products show similar patterns) derived from the basic $\mathrm{N} \pm \delta \mathrm{S} \pm \delta$ scenarios. National level results are summarized in Table 4. Climate-induced reductions in southern yields (the $\mathrm{N}+\delta \mathrm{S}-\delta$ cases) lead to reduced southern product output (Fig. 3b) and shorter timber rotations (Fig. 3h). ${ }^{7}$ Output reductions in the South are generally matched by increases in northern production (Fig. 3a), suggesting the possibility of 'migration' of production to the northern regions. Again, this is a result

\footnotetext{
${ }^{7}$ In this case the reduction in physical volume growth of the timber is not offset by the acceleration in price growth and harvest ages must fall
}

(a) Producers' Welfare



(b) Consumers' Welfare



(c) Total Welfare

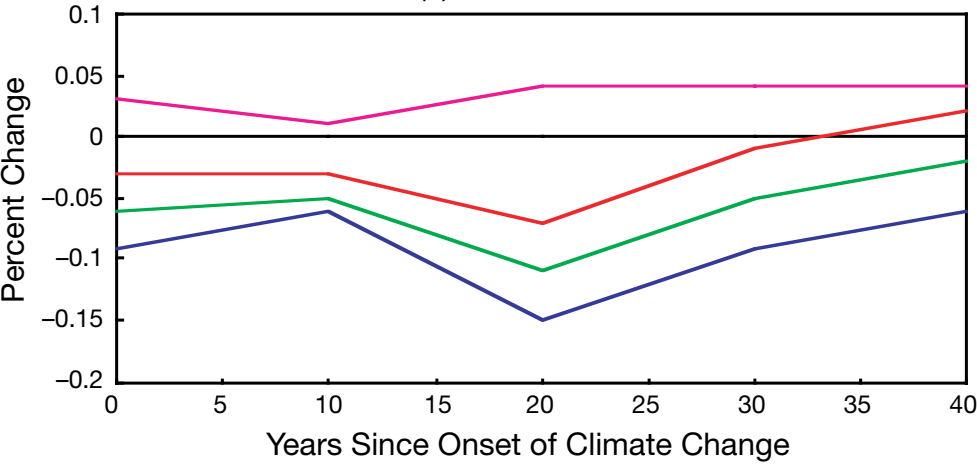

Fig. 2. Changes in welfare measures over time for simple plus and minus $1 \%$ growth change scenarios. The changes in a simple scenario, such as $\mathrm{S}-1 \mathrm{~N}-1$, which involves a $1 \%$ reduction in both South and North forest growth, are tracked over time using separate response function equaons estimated for individual time periods. Black: no climate change,

blue: $\mathrm{N}-\delta / \mathrm{S}-\delta$, green: $\mathrm{S}-\delta / \mathrm{N} 0$, violet: $\mathrm{S} 0 / \mathrm{N}+\delta$, and red: $\mathrm{S}-\delta / \mathrm{N}+\delta$

commonly found in most agricultural studies (Adams et al. 1990, 1998, 1999, Lewandrowski \& Schimmelpfennig 1999). The net effect of higher prices (Fig. 3e,f) and higher growth in the North (in the $\mathrm{N}+\delta \mathrm{S}-\delta$ cases) is longer rotations with higher volumes at harvest during the first $20 \mathrm{yr}$ of the projection (Fig. 3g). Adaptation is also seen as changing product mixes, with sawtimber use gaining at the expense of pulpwood production (Fig. 3c,d). In scenarios where southern growth reductions are not matched with gains in the North (the N0 $\mathrm{S}-\delta$ and $\mathrm{N}-\delta \mathrm{S}-\delta$ cases), total US sawtimber production falls and higher prices force consumer substitution adjustments and reduced use of wood. 
(a) Northern Softwood sawtimber HARVEST

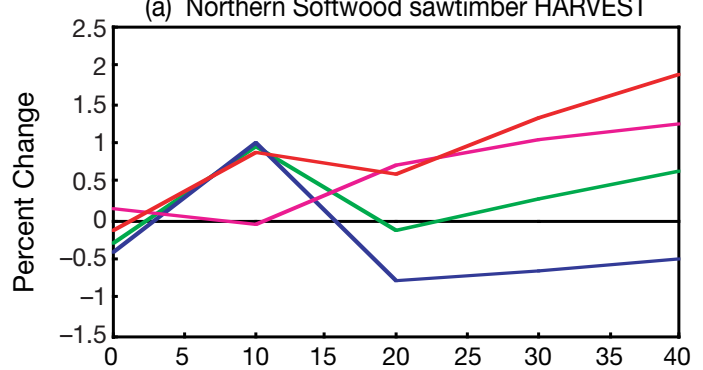

(b) Southern Softwood sawtimber HARVEST

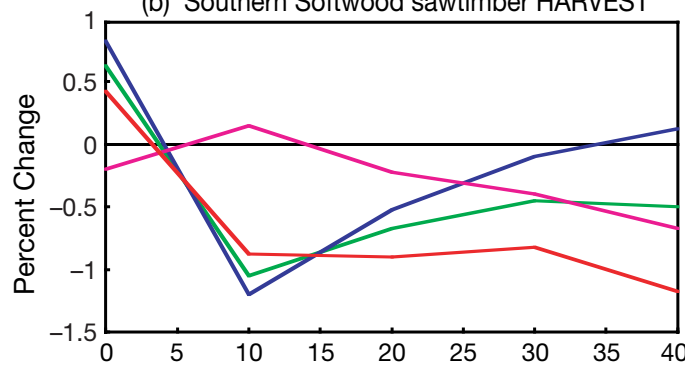

(c) National Softwood sawtimber HARVEST

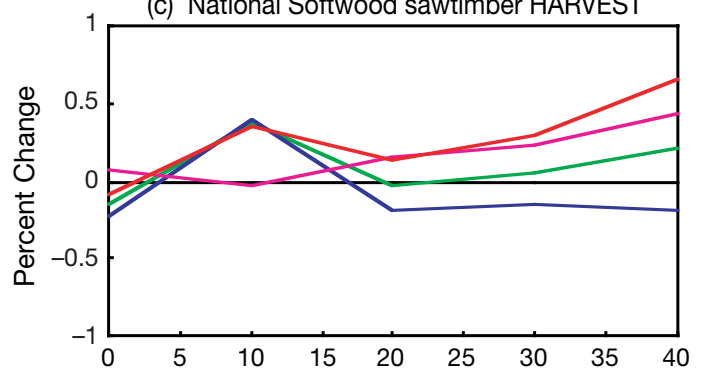

(d) National Softwood Pulp HARVEST

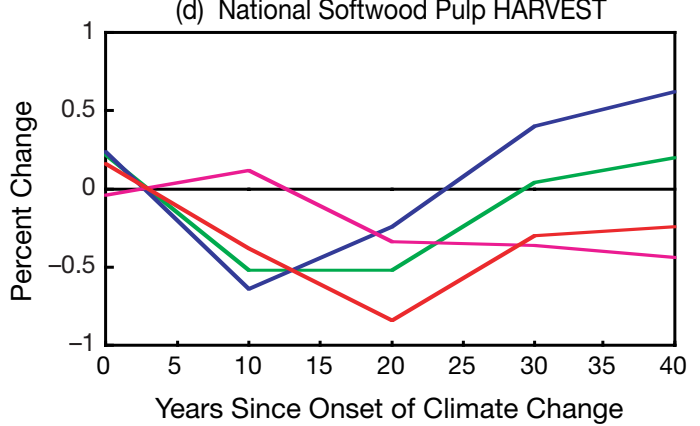

(e) Softwood sawtimber Price


(g) Average Rotation Age in the North



(h) Average Rotation Age in the South



Fig. 3. Effect of simple plus and minus $1 \%$ growth change scenarios on national and regional production, prices and forest management (rotation age). Black: no climate change, blue: $\mathrm{N}-\delta / \mathrm{S}-\delta$, green: $\mathrm{S}-\delta / \mathrm{N} 0$, violet: $\mathrm{S} 0 / \mathrm{N}+\delta$, and red: $\mathrm{S}-\delta / \mathrm{N}+\delta$

\section{CONCLUDING COMMENTS}

The magnitude of changes in forest yield is critical to the estimation of the economic implications of climate change for the US forest sector. At present, however, estimates of impacts of climate change on forest yields have a wide range of uncertainty. As a result, we developed response functions that provide summaries of the projected influence of growth rate alterations on current and future economic perfor- mance in the forest sector. The functions may be used by others to evaluate the consequences of specific scenarios of forest climate change and to readily revise these estimates as new findings on climatic effects arise.

We also used the functions to illustrate some general sectoral response characteristics to climate change that emerge in the FASOM model results. Although the aggregate sectoral welfare effects (consumers' savings plus producers' profits) are relatively limited even under 
Table 4. Effects of 4 scenarios of regional variation using plus and minus $1 \%$ growth impacts on economic welfare and market measures at the national level. NPV: net present value; 1st dec, 2nd dec, etc.: decades since onset of growth changes. The scenarios are denoted as $\mathrm{S}+\delta \mathrm{N}+\varepsilon$, where $\mathrm{S}+\delta$ refers to base levels of forest growth in the South plus $\delta$ percent and $\mathrm{N}+\varepsilon$ refers to base levels of forest growth in the North plus $\varepsilon$ percent (where $\delta$ and $\varepsilon$ may be $-1,0$, or +1 )

\begin{tabular}{|c|c|c|c|c|c|c|c|}
\hline \multirow[t]{2}{*}{ Measure } & \multirow[t]{2}{*}{ Unit } & \multirow[t]{2}{*}{ Time } & \multirow{2}{*}{$\begin{array}{l}\text { Base } \\
\text { level }\end{array}$} & \multicolumn{4}{|c|}{ Change from base level } \\
\hline & & & & $\mathrm{S}-1 \mathrm{~N} 0$ & $\mathrm{~S}-1 \mathrm{~N}-1$ & $\mathrm{~S} 0 \mathrm{~N}+1$ & $\mathrm{~S}-1 \mathrm{~N}+1$ \\
\hline \multirow{2}{*}{$\begin{array}{l}\text { Producers' } \\
\text { surplus }\end{array}$} & \multirow[t]{2}{*}{ Million $2000 \$$} & NPV & \multirow[t]{2}{*}{251315} & 7775 & 13025 & -5022 & 2567 \\
\hline & & $\%$ chg & & 3.090 & 5.180 & -2.000 & 1.020 \\
\hline \multirow{2}{*}{$\begin{array}{l}\text { Consumers' } \\
\text { surplus }\end{array}$} & \multirow{2}{*}{ Million $2000 \$$} & NPV & \multirow{2}{*}{2860082} & -9667 & -16121 & 6193 & -3249 \\
\hline & & \%chg & & -0.340 & -0.560 & 0.220 & -0.110 \\
\hline \multirow[t]{2}{*}{ Foreign surplus } & \multirow[t]{2}{*}{ Million $2000 \$$} & NPV & \multirow[t]{2}{*}{7107} & -32 & -53 & 21 & -10 \\
\hline & & $\% \operatorname{chg}$ & & -0.440 & -0.750 & 0.290 & -0.140 \\
\hline \multirow[t]{2}{*}{ Total welfare } & \multirow[t]{2}{*}{ Million $2000 \$$} & NPV & \multirow[t]{2}{*}{3212872} & -1980 & -4262 & 2241 & 303 \\
\hline & & $\% \operatorname{chg}$ & & -0.060 & -0.130 & 0.070 & 0.010 \\
\hline \multirow{10}{*}{$\begin{array}{l}\text { Softwood } \\
\text { sawtimber } \\
\text { price }\end{array}$} & \multirow[t]{10}{*}{$2000 \$$ per cubic ft } & 1st dec & 2.110 & 0.010 & 0.015 & -0.005 & 0.005 \\
\hline & & \%chg & & 0.470 & 0.710 & -0.260 & 0.220 \\
\hline & & 2nd dec & 2.250 & 0.014 & 0.022 & -0.008 & 0.006 \\
\hline & & $\% \operatorname{chg}$ & & 0.620 & 0.970 & -0.360 & 0.260 \\
\hline & & 3rd dec & 1.930 & 0.023 & 0.036 & -0.012 & 0.011 \\
\hline & & \%chg & 1.180 & 1.840 & -0.610 & 0.540 & \\
\hline & & 4 th dec & 1.900 & 0.024 & 0.042 & -0.017 & 0.007 \\
\hline & & \%chg & 1.280 & 2.200 & -0.870 & 0.360 & \\
\hline & & 5 th dec & 1.670 & 0.017 & 0.034 & -0.015 & 0.001 \\
\hline & & \%chg & 1.010 & 2.020 & -0.890 & 0.060 & \\
\hline Softwood & $2000 \$$ per cubic ft & 1.520 & 0.010 & 0.015 & -0.005 & 0.005 & \\
\hline pulpwood & & \%chg & & 0.650 & 0.980 & -0.360 & 0.300 \\
\hline price & & 2nd dec & 1.640 & 0.013 & 0.020 & -0.007 & 0.006 \\
\hline & & $\% \operatorname{chg}$ & & 0.800 & 1.240 & -0.450 & 0.350 \\
\hline & & 3rd dec & 1.260 & 0.003 & 0.003 & 0.000 & 0.004 \\
\hline & & $\%$ chg & & 0.270 & 0.270 & 0.010 & 0.280 \\
\hline & & 4th dec & 1.290 & 0.006 & 0.004 & 0.002 & 0.008 \\
\hline & & \%chg & & 0.440 & 0.320 & 0.160 & 0.600 \\
\hline & & 5 th dec & 1.510 & 0.009 & 0.013 & -0.004 & 0.005 \\
\hline & & \%chg & & 0.620 & 0.890 & -0.290 & 0.310 \\
\hline Softwood & 1000 cubic ft & 1 st dec & 90155 & -135 & -200 & 66 & -70 \\
\hline sawtimber & & \%chg & & -0.150 & -0.220 & 0.070 & -0.080 \\
\hline production & & 2nd dec & 81809 & 302 & 316 & -19 & 283 \\
\hline & & \%chg & & 0.370 & 0.390 & -0.020 & 0.350 \\
\hline & & 3rd dec & 88506 & -24 & -158 & 142 & 121 \\
\hline & & \%chg & & -0.030 & -0.180 & 0.160 & 0.140 \\
\hline & & 4 th dec & 90428 & 53 & -131 & 210 & 263 \\
\hline & & \% chg & & 0.060 & -0.150 & 0.230 & 0.290 \\
\hline & & 5 th dec & 99706 & 221 & -183 & 441 & 669 \\
\hline & & $\%$ chq & & 0.220 & -0.180 & 0.440 & 0.670 \\
\hline Softwood & 1000 cubic ft & 1 st dec & 25880 & 56 & 66 & -9 & 45 \\
\hline pulpwood & & \%chg & & 0.220 & 0.250 & -0.040 & 0.170 \\
\hline production & & 2nd dec & 30417 & -156 & -191 & 38 & -117 \\
\hline & & \%chg & & -0.510 & -0.630 & 0.120 & -0.380 \\
\hline & & 3rd dec & 55378 & -285 & -131 & -180 & -458 \\
\hline & & \%chg & & -0.520 & -0.240 & -0.330 & -0.830 \\
\hline & & 4 th dec & 52580 & 26 & 214 & -191 & -159 \\
\hline & & \%chg & & 0.050 & 0.410 & -0.360 & -0.300 \\
\hline & & 5 th dec & 58128 & 121 & 364 & -258 & -139 \\
\hline & & \%chg & & 0.210 & 0.630 & -0.440 & -0.240 \\
\hline
\end{tabular}

extreme scenarios, this arises because of marked economic welfare shifts between producers and consumers. Yield increases induced by climate change were found to benefit consumers but not producers, while yield decreases have the opposite effect. The forest sector was also found to have adaptive adjust- ment characteristics, including regional (in our example, northerly) migration of production, substitution in consumption between wood and non-wood products and between sawtimber and pulpwood, and the ability to alter the intensity of forest management (rotation age) among owners and regions. 
Acknowledgements. This research was sponsored by the USDA, Forest Service, Texas Agricultural Experiment Station, and the US Environmental Protection Agency.

\section{LITERATURE CITED}

Adams DM, Haynes RW (1996) The 1993 timber assessment market model: structure, projections and policy simulations. General Technical Report PNW-GTR-358, USDA, Forest Service, PNW Research Station, Portland, OR

Adams RM and 9 others (1990) Global climate change and US agriculture. Nature 345:219-224

Adams DM, Alig RJ, McCarl BA (1996) An analysis of the impacts of public timber harvest policies on private forest management in the U.S. For Sci (1996):343-358

Adams DM, Alig RJ, McCarl BA, Callaway J, Winnett S (1997) The forest and agricultural sector optimization model: model structure and applications. Research Paper PNWRP-495, USDA, Forest Service, Portland, OR

Adams RM, Hurd BH, Lenhart S, Leary N (1998) Effects of global climate change on agriculture: an interpretative review. Clim Res 11:19-30

Adams RM and 8 others (1999) Climate change and U.S. agriculture: some further evidence. Agric Resour Econ Rev Socieconomic studies from the 1994 SOFEW meeting, General technical report, SE-92, USDA

Alig RJ, Adams DM, McCarl BA (1998) Impacts of incorporating land exchanges between forestry and agriculture in sector models. J Agric Appl Econ 30(2):389-401

Burton D, McCarl BA, Adams DM, Alig R, Callaway J (1994) An exploratory study of the economic impacts of climate change on southern forests: preliminary results. In: Proceedings of the southern forest economics workshop; 1994, March; Savannah, GA

Burton D, McCarl BA, Adams DM, Alig R, Callaway J (1998) Economic dimensions of climate change impacts on southern forests. In: Fox S, Mickler RA (eds) The productivity and

Editorial responsibility: Laurence Kalkstein,

Newark, Delaware, USA sustainability of southern forest ecosystems in a changing environment (Chap 42). Springer, New York, p 777-794

Callaway JM, Smith J, Keefe S (1994) The economic effects of climate change for U.S. forests. U.S. Environmental Protection Agency, Adaptation Branch, Climate Change Division, Office of Policy, Planning, and Evaluation. Washington, DC

Haynes RW, Adams DM, Mills J (1995) The 1993 RPA timber assessment update. General Technical Report RM-259, USDA, Forest Service, Rocky Mountain Forest and Range Experiment Station, Fort Collins, CO

Joyce LA and 5 others (1995) Forest sector impacts from changes in forest productivity under climate change. J Biogeogr 22:703-713

Kane S, Reilly J, Tobey J (1992) An empirical study of the economic effects of climate change on world agriculture. Clim Change 21:17-35

Lewandrowski J, Schimmelpfennig D (1999) Economic implications of climate change for U.S. agriculture: assessing recent evidence. Land Econ 75:39-57

Perez-Garcia J, Joyce LA, Binkley C, McGuire A (1997) Economic impacts of climate change on the global forest sector: an integrated ecological/economic assessment. Crit Rev Environ Sci Technol 27(Special):S123-S138

Sohngen B, Mendelsohn R (1998) Valuing the impact of largescale ecological change in a market: the effect of climate change on U.S. timber. Am Econ Rev 88:686-710

Sohngen B, Mendelsohn R, Neilson R (1998) Predicting $\mathrm{CO}_{2}$ emissions from forests during climatic change: a comparison of natural and human response models. Ambio 27(7): 509-513

Van Kooten GC (1990) Climate change impacts on forestry: economic issues. Can J Agric Econ 38:701-710

Van Kooten GC, Arthur LM (1989) Assessing economic benefits of climate change on Canada's boreal forest. Can J For Res 19:464-470

Winnett SM (1998) Potential effects of climate change on U.S. forests: a review. Clim Change 11:39-49

Submitted: May 10, 1999; Accepted: February 9, 2000

Proofs received from author(s): June 19, 2000 